\title{
COMPARISON OF HEMODYNAMIC STATUS AND COMPLICATIONS BETWEEN TWO DIFFERENT DOSES OF INTRAMYOMETRIAL VASOPRESSIN DURING LAPAROSCOPIC MYOMECTOMY: A RETROSPECTIVE STUDY, THE LESSER THE BETTER
}

\author{
NUPUR MODA, SUSHREE DAS, MADHUSMITA PATRO, PRERNA BISWAL*
}

Department of Anesthesiology and Pain Medicine, Institute of Medical Sciences and SUM Hospital, Bhubaneswar, Odisha, India Email: prerna.biswal@gmail.com

Received: 25 June 2021, Revised and Accepted: 10 September 2021

\section{ABSTRACT}

Objective: Our aim is comparison of hemodynamic status and complications between two different doses of intramyometrial vasopressin during laparoscopic myomectomy.

Methods: We did a retrospective analysis of hemodynamic status and its anesthetic concerns in patients who received two different doses of intramyometrial vasopressin. Eighty patients undergoing laparoscopic myomectomy under general anesthesia were divided into two groups of 40 patients in each group. In Group A ( $\mathrm{n}=40), 10$ units of intramyometrial vasopressin in $200 \mathrm{ml}$ of normal saline were given and, in Group B, 20 units of intramyometrial vasopressin in $200 \mathrm{ml}$ of NS were given intraoperatively by surgeon.

Results: 20 units intramyometrial vasopressin used dogmatically by surgeons drops blood loss but it is connected with cardiovascular impediments. Hence, 10 units of intramyometrial vasopressin as compared to 20 units which are used by some surgeons are associated with similar blood loss and lesser side effects such as bradycardia, pulmonary edema, hypotension, blood loss, and increased airway pressure.

Conclusion: Hence, anesthesiologists and gynecologists must take the precautions to escape and minimize the frequency of impediments with intramyometrial vasopressin by selecting the appropriate dosage of vasopressin.

Keywords: Intramyometrial vasopressin, Myomectomy, Bradycardia, Pulmonary edema, Hypotension.

(c) 2021 The Authors. Published by Innovare Academic Sciences Pvt Ltd. This is an open access article under the CC BY license (http://creativecommons.org/ licenses/by/4.0/) DOI: http://dx.doi.org/10.22159/ajpcr.2021v14i10.42927. Journal homepage: https://innovareacademics.in/journals/index.php/ajpcr

\section{INTRODUCTION}

Uterine leiomyoma is the most extensively recognized sort of pelvic tumors in women [1].When a uterine myoma creates, the ordinary life systems of uterine veins are disturbed, and the vessels run in unusual ways. Myomectomy causes vascular injury paying little heed to the bearing of the entry point and results in extreme blood loss [2]. Vasopressin is a synthetic analog of the anti-diuretic hormone; it causes vasoconstriction through its activity on V1 receptors and against diuresis through V2 receptors in the kidney [3]. Intramyometrial infusion of vasopressin causes vasoconstriction, stimulates the uterine contractions and therefore it reduces the blood loss during surgery $[4,5]$. However, vasopressin was reported to be associated with severe complications such as bradycardia, arrhythmias, pulmonary edema, and cardiac arrest [6-9]. The variations in heart rate (HR) and blood pressure after intramyometrial vasopressin injection might be correlated to the systemic absorption of vasopressin especially during the surgical excisions of the fibroid and not linked to the direct intravascular injection. Studies have proven that vasopressin was injected after negative blood aspiration during injection and second the hemodynamic changes did not happen during vasopressin injection but after $10 \mathrm{~min}$ of vasopressin injection in most of the cases. The injection of diluted vasopressin into the plane between the myoma and myometrium leads to vasoconstriction of the feeding vessels for 45-60 min which is usually sufficient for the myometrial suturing to be accomplished and therefore reducing the blood flow to the myoma and lessening the blood loss during the excision of the myoma [10-12]. There are discussions and encounters between the surgeons and anesthesiologists regarding the risks and advantages of vasopressin and therefore, this study was conducted to evaluate the incidence of cardiovascular complications associated with the intramyometrial injection of vasopressin. Hence, our aim here is to look for the changes in hemodynamic status and complications after two different doses of intramyometrial vasopressin and to look for any difference in blood loss in both groups.

\section{METHODS}

It is a retrospective observational study at the Department of Anesthesiology, Institute of Medical Sciences and SUM Hospital. Data were collected from April 2017 to July 2018 at MRD department of IMS and SUM hospital after obtaining approval from the institutional ethical committee. A total of 80 patients undergoing laparoscopic myomectomy under general anesthesia were divided into two groups of 40 each. In Group A ( $\mathrm{n}=40), 10$ units of intramyometrial vasopressin in $200 \mathrm{ml}$ of NS were used and, in Group B ( $n=40), 20$ units of intramyometrial vasopressin in $200 \mathrm{ml}$ of NS were used for infiltration by surgeon.

\section{Inclusion criteria}

The following criteria were included in the study:

- $\quad$ ASA - Grades 1 and 2

- $\quad$ Age (18-35 years)

- Patients who had not received spinal anesthesia.

Standard balanced general anesthesia and Standard monitoring techniques were followed.

Within 2-3 min of injection of intramyometrial vasopressin, there was decrease in the HR $(<50)$, along with a significant drop in the mean arterial pressures $(<60 \mathrm{mmHg}$ ). However, there was no change in the electrocardiogram or the endtidal carbon dioxide (EtCO2) waveform and its values. These changes are more marked in patients in Group B. The changes reverted back to baseline in 15-25 min time as documented. 
Following data were collected for the study purpose

- General information about the patients such as age, sex, height, and weight including duration of surgery and anesthesia

- Baseline vital parameters such as HR and blood pressure (mean arterial pressure) noted in all patients preoperatively

- Intraoperative HR, systolic and diastolic blood pressure, oxygen saturation, $\mathrm{ETCO}_{2}$, and airway pressures were noted starting from injection of intramyometrial vasopressin till $30 \mathrm{~min}$ of injection at 5 min interval

- The amount of blood loss noted in all patients

- Any adverse events such pulmonary edemas and arrhythmias were noted

- Patients with HR $<50$ beats/min were considered to have symptomatic bradycardia

- Mean arterial blood pressure $<60 \mathrm{~mm}$ of Hg was considered to have hypotension

- Airway pressure $>40 \mathrm{mmHg}$ was taken as significant

Data were collected and entered into Microsoft Excel 2007 and analysis was performed using SPSS version 20.0. The entire categorical variable was expressed in terms of number and percentages. Comparison between categorical variables was performed using Chi-square test. All continuous variables were expressed in terms of mean and SD. Comparison between continuous variables was performed using unpaired t-test. $\mathrm{p}<0.05$ was considered statistically significant

\section{RESULTS}

In our study, we found that the demographic profile of both the groups was similar in terms of age, weight, height, duration of surgery, and duration of anesthesia with $\mathrm{p}>0.05$ (Table 1 ).

Blood loss was almost similar in both the groups. Group A had mean blood loss of $264 \pm 20.43 \mathrm{ml}$ and Group B had mean blood loss of $213 \pm 18.35 \mathrm{ml}$. The p-value between two groups is 0.601 which is statistically insignificant. Bradycardia and hypotension occurred in $50 \%$ of Group B patients as compared to $20 \%$ in Group A patients with $*$ p- $=0.034$ which is statistically significant. Airway pressure was increased in $12.5 \%$ patients of Group B as compared to $2.5 \%$ in Group A, the difference being statistically significant with ${ }^{*}$ p-value $=0.041$. Pulmonary edema occurred in $10 \%$ of Group B patients and none of Group A patients, p-value being different statistically, ${ }^{*}$ p-value $=0.04$ (Table 2 and Fig. 1).

\section{DISCUSSION}

One of the key attentions for the doctors during resection of significantly vascular tumors such as uterine myomas (fibroid) is extreme bleeding that might be life threatening. Several mechanical and pharmacological interventions are used to diminish blood loss. Vasopressin is an hemostatic agent recycled for over and above 50 years, and there are published data reports supporting the usage of vasopressin to decrease blood loss during myomectomy. Likewise, there are published reports of adverse cardiac events that include cardiac arrest following vasopressin management [13-15]. These cardiac results are potentiated in patients with coronary insufficiency. Vasopressin causes decreased HR and decreased cardiac output due to coronary vasoconstriction, potentiated baroreflex due to generalized vasoconstriction. Although it causes global vasoconstriction, it clinically manifests as global hypotension [16]. Failure to identify this will lead to treatment with vasopressors that can worsen the cardiac complications. The hemostatic property of vasopressin is well addressed in many studies, but the safe total dose and concentration is still controversial $[17,18]$. Frishman recommended intramyometrial dose of 4-6 $\mathrm{U}$ at a concentration $0.2 \mathrm{U} / \mathrm{ml}$ to be safe, based on assumption that low dose and low concentration are equally effective in achieving hemostasis without cardiac complications [19]. In our study, we also found that less complications occur with low doses (Table 2 and Fig. 1). 10 units of vasopressin causes similar blood loss as compared to 20 units with lesser side effects such as hypotension, bradycardia, pulmonary edema, and increased airway pressures.
Table 1: Demographic profile of both the patient Groups A and B with duration of surgery and anesthesia

\begin{tabular}{|c|c|c|c|}
\hline Characteristics & $\begin{array}{l}\text { Group A } \\
(n=40) \\
(\text { Mean } \pm S D)\end{array}$ & $\begin{array}{l}\text { Group B } \\
(n=40) \\
(\text { Mean } \pm S D)\end{array}$ & p-value* \\
\hline Age (in years) & $40.12 \pm 5.23$ & $41.04 \pm 4.23$ & 0.456 \\
\hline Weight (kg) & $65.3 \pm 4.56$ & $66.2 \pm 5.65$ & 0.543 \\
\hline Height $(\mathrm{cm})$ & $160.5 \pm 10.65$ & $162.5 \pm 11.57$ & 0.488 \\
\hline $\begin{array}{l}\text { Duration of surgery } \\
\text { (min) }\end{array}$ & $45.6 \pm 12.43$ & $46.4 \pm 13.23$ & 0.786 \\
\hline $\begin{array}{l}\text { Duration of anesthesia } \\
\text { (min) }\end{array}$ & $60.23 \pm 10.15$ & $62.54 \pm 11.21$ & 0.406 \\
\hline
\end{tabular}

*Unpaired t-test was used

Table 2: Comparison between incidences of adverse events in both the groups

\begin{tabular}{|c|c|c|c|}
\hline Adverse events & $\begin{array}{l}\text { Group A } \\
(n=40)\end{array}$ & $\begin{array}{l}\text { Group B } \\
(n=40)\end{array}$ & p-value \\
\hline Bradycardia & $08(20 \%)$ & $20(50 \%)$ & 0.034 \\
\hline Hypotension & $08(20 \%)$ & $20(50 \%)$ & 0.034 \\
\hline $\begin{array}{l}\text { Increased airway } \\
\text { pressure }\end{array}$ & $01(2.5 \%)$ & $05(12.5 \%)$ & 0.041 \\
\hline Arrhythmia & 00 & 00 & -- \\
\hline Pulmonary edema & 00 & $04(10 \%)$ & 0.04 \\
\hline Blood loss (ml) & $264 \pm 20.43$ & $213 \pm 18.35$ & 0.601 \\
\hline
\end{tabular}

${ }^{*}$ Chi-squared test was used to calculate $\mathrm{p}$-value

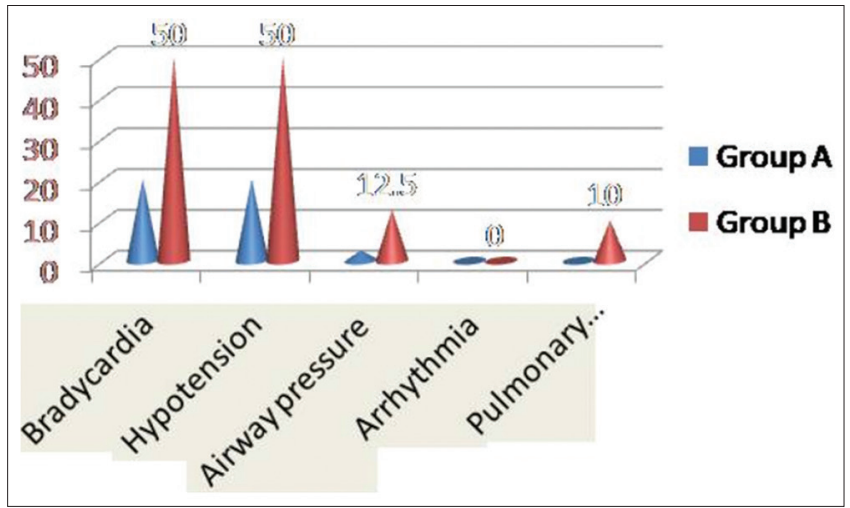

Fig. 1: Adverse effect with two doses of vasopressin

\section{Limitations}

We have studied a smaller group of population which may not provide the accurate result. We have done a retrospective analysis so real time assessment of problems could not be done. Large-scale trials should be done on intramyometrial dose and concentration to find out the safe dose and concentration of vasopressin. A prospective study should be done to analyze and compare the doses. We report these studies to alert the anesthesiologists so that guidelines can be framed regarding the dose, concentration and the continued use of vasopressin and if there are any other alternatives to vasopressin available.

\section{CONCLUSION}

Guidelines including the safe dose and concentration of intramyometrial vasopressin and proper patient selection are warranted. Close communication between the anesthesiologist and gynecologist regarding correct dose of vasopressin is of paramount importance to prevent, identify and treat the complications related to intramyometrial vasopressin infiltration. If lesser dose of intramyometrial vasopressin injection is causing similar blood loss with lesser side effects, then it is a matter of concern while selecting the appropriate dosage. 


\section{AUTHORS CONTRIBUTION}

1. Dr. Nupur Moda-Acquisition of data, writing manuscript, interpretation of data

2. Dr. Sushree Das-Acquisition of data, concept and designing, data collection

3. Dr. Madhusmita Patro-Writing the manuscript, data collection

4. Dr. Prerna Biswal-Interpretation of data, writing manuscript, final approval, corresponding author.

\section{CONFLICTS OF INTEREST}

None.

\section{AUTHORS FUNDING}

None.

\section{REFERENCES}

1. Cramer SF, Patel A. The frequency of uterine leiomyomas. Am J Clin Pathol 1990; 94:435-8.

2. Zeqja E, Qirko R. Vasopressine in laparoscopic myomectomy, a review over the effectiveness, dosage and possible complications. IOSR J Pharm 2016; 6:23-7.

3. Wing DA, Goharkhay N, Felix JC, Rostamkhani M, Naidu YM, Kovacs BW. Expression of the oxytocin and V1a vasopressin receptors in human myometrium in differing physiologic states and following misoprostol administration. Gynecol Obstet Invest 2006; 62:181-5.

4. Shimanuki H, Takeuchi H, Kitade M, Kikuchi I, Kumakiri J, Kinoshita K. The effect of vasopressin on local and general circulation during laparoscopic surgery. J Minim Invasive Gynecol 2006; 13:190- 4.

5. Takeuchi H, Shimanuki H, Kobori H, Kitade M, Kikuchi I, Kinoshita K. Effect of vasopressin on blood flow and RI of the uterine artery during laparoscopic myomectomy. J Minim Invasive Gynecol 2005; 12:10-1.

6. Nezhat F, Admon D, Nezhat CH, Dicorpo JE, Nezhat C. Lifethreatening hypotension after vasopressin injection during operative laparoscopy, followed by uneventful repeat laparoscopy. J Am Assocc
Gynecol Laparosc 1994; 2:83-6.

7. Hobo R, Netsu S, Koyasu Y, Tsutsumi O. Bradycardia and cardiac arrest caused by intramyometrial injection of vasopressin during a laparoscopically assisted myomectomy. Obstet Gynecol 2009; 113:484- 6.

8. Kimura T, Kucui C. Effectiveness of hormonal tourniquet by vasopressin during myomectomy through vasopressin V1a receptor ubiquitously expressed in myometrium. Gynecol Obstet Invest 2002; 54:125-31.

9. Park KS, Yoo KY. Role of vasopressin in current anesthetic practice. Korean J Anesthesiol 2017; 70:245-57.

10. Tsuda A, Kanaoka Y. Submyometrial vasopressin injection before microwave ablation of vascular-rich submucosalmyomas: A preliminary case study. Int J Hyperthermia 2019; 36:739-43.

11. Kakkar B. Is Irrational use of intramyometrial vasopressin justified in anesthesia practice? Anaesth Commun 2017; 1:e102.

12. Malla UJ, Rong ZS. Role of vasopressin in myomectomy. IJSIT 2018; 7:183-7.

13. Dillon TF, Marbury BE, Bonsnes RW, Douglas RG, DuVigneaud V. Vasopressin as a hemostatic in gynecologic surgery; a preliminary report. Obstet Gynecol 1958; 11:363-71.

14. Fletcher H, Frederick J, Hardie M, Simeon D. A randomized comparison of vasopressin and tourniquet as hemostatic agents during myomectomy. Obstet Gynecol 1996; 87:1014-8.

15. Jayaraman L, Sinha A, Punhani D. Intramyometrial vasopressin: Anesthesiologists' nightmare. J Anaesthesiol Clin Pharmacol 2013; 29:135-6.

16. Riess ML, Ulrichs JG, Pagel PS, Woehlck HJ. Case report: Severe vasospasm mimics hypotension after high-dose intrauterine vasopressin. Anesth Analg 2011; 113:1103-5.

17. Barett KE, Boitano S, Barman SM, Brooks HL. Ganong's Review of Medical Physiology. 24 ${ }^{\text {th }}$ ed. New York: McGraw-Hill; 2012.

18. American Heart Association. Guidelines for cardiopulmonary resuscitation and emergency cardiovascular care: Part 7.3: Management of symptomatic bradycardia and tachycardia. Circulation 2005; 112:67- 77.

19. Frishman G. Vasopressin: If some is good, is more better? Obstet Gynecol 2009; 113:476-7. 